Published in final edited form as:

Histopathology. 2020 January ; 76(2): 222-232. doi:10.1111/his.13960.

\title{
CCR4 expression in CD8+ cutaneous T-cell lymphomas and lymphoproliferative disorders and its implications for diagnosis and treatment.
}

\author{
Shamir Geller ${ }^{1,4}$, Travis J. Hollmann², Steven M. Horwitz ${ }^{3}$, Patricia L. Myskowski ${ }^{1}$, Melissa \\ Pulitzer $^{2}$ \\ ${ }^{1}$ Dermatology Service, Department of Medicine, Memorial Sloan Kettering Cancer Center and \\ Weill Cornell Medical College, New York, NY, USA \\ ${ }^{2}$ Department of Pathology, Memorial Sloan Kettering Cancer Center and Weill Cornell Medical \\ College, New York, NY, USA \\ ${ }^{3}$ Department of Medicine, Lymphoma Service, Memorial Sloan Kettering Cancer Center, New \\ York, NY, USA
}

${ }^{4}$ Department of Dermatology, Tel Aviv Sourasky Medical Center, Tel Aviv, Israel

\section{Abstract}

\begin{abstract}
Aims: Patients with aggressive CD8+ cutaneous T-cell lymphoma (CTCL) progress rapidly and respond poorly to therapy. Confounding treatment planning, there is clinicopathologic overlap between aggressive CD8+ CTCL and other lymphoproliferative disorders (LPD). Hence, improved diagnostic methods and therapeutic options are needed. We examined C-C chemokine receptor 4 (CCR4) expression as a diagnostic and therapeutic biomarker in CD8+ CTCL/LPDs.
\end{abstract}

Methods and results: Forty-nine cases (41 patients) with CD8+ CTCL/LPDs were examined, including CD8+ MF ( $\mathrm{n}=14$ ), aggressive epidermotropic CD8+ cytotoxic T-cell lymphoma (AETCL, $n=8$ ), subcutaneous panniculitis-like T-cell lymphoma (SPTCL, n=7), CD30+ LPD $(\mathrm{n}=6)$, primary cutaneous $\gamma \delta$ T-cell lymphoma (GDTCL, $n=6)$ and others $(\mathrm{n}=8)$.

Immunohistochemical tissue staining was performed using a CCR4 monoclonal antibody on formalin-fixed, paraffin-embedded tissue sections. CCR4 immunostaining was graded as percentage infiltrate: high (>25\%) and low (25\% or less) and the results were correlated with clinicopathologic diagnoses. CCR4 expression was seen in $69 \%$ of the studies cases. Any CCR4 positivity was seen in all CD8+ MF cases, in $83 \%$ of CD30+ LPD, $75 \%$ of AETCL, 33\% of

\footnotetext{
Corresponding author: Shamir Geller, MD, Dermatology Service, Memorial Sloan Kettering Cancer Center, 16 East 60th Street, New York, NY 10022, USA, Tel: (646) 8886032 shamirgeller@gmail.com.

Author contributions: Melissa Pulitzer - concept design, data acquisition, analysis \& interpretation, writing/drafting, supervision, critical revision; Shamir Geller - writing/drafting, data acquisition, analysis \& interpretation, critical revision;

Travis Hollmann - data acquisition (performed IHC), writing/revising, critical revision; Steven Horwitz, Patricia Myskowski - data acquisition, critical revision

Conflict of interest disclosures: Steve M. Horwitz has received both research funding/grant support and honoraria/consulting fees from ADCT Therapeutics, Aileron, Forty-Seven Infinity/Verastem Kyowa-Hakka-Kirin, Millennium / Takeda and Seattle Genetics; Research/grant support from Celgene and Trillium; and honoraria consulting fees from Affimed, Angimmune, Beigene, Corvus, Innate Pharma, Kura, Merck, Miragen, Mundipharma, Portola, and Syros Pharmaceutical. All other authors have no conflict of interest to declare.
} 
GDTCL and in none of the SPTCL cases. High CCR4 expression was seen in 79\% of CD8+ MF versus $33 \%$ of CD30+ LPD, $17 \%$ of GDTCL, $12.5 \%$ of AETCL cases. Patients with more advanced MF stage had higher CCR4 expression.

Conclusions: CCR4 immunohistochemistry may be an adjunct in distinguishing advanced CD8+ MF from other CD8+ CTCL/LPDs. While CCR4 expression may justify therapeutic targeting of this receptor in CD8+ MF, the role of such therapies in other CD8+ CTCL/LPDs is not yet clear.

\section{Keywords}

cutaneous T-cell lymphoma; CTCL; mycosis fungoides; MF; mogamulizumab; immunotherapy; cell marker; chemokine

\section{Introduction}

CD8+ cutaneous T-cell lymphomas (CTCL) and lymphoproliferative disorders (LPD) comprise a heterogeneous group of disorders with widely variable prognoses and beg differing therapeutic approaches despite some overlapping clinicopathologic features. ${ }^{1,2} \mathrm{An}$ indolent course is seen in CD8+ mycosis fungoides (MF), ${ }^{3,4}$ lymphomatoid papulosis (LyP) types $\mathrm{D},{ }^{5} \mathrm{E}^{6}$ and subcutaneous panniculitis-like T-cell lymphoma (SPTCL), ${ }^{7,8}$ while aggressive behavior is seen in aggressive epidermotropic CD8+ cytotoxic T-cell lymphoma $(\mathrm{AETCL})^{9}$ and cases of CD8+ primary cutaneous gamma delta T-cell lymphoma (GDTCL). 8, 10 Therapies for these rare disorders are determined by classification as per current cutaneous lymphoma guidelines. ${ }^{11}$ Patients with each of these aggressive disorders often fail current therapeutic options over time, thus there is a continued search for alternative new therapies, which may be rationalized by the identification of potential therapeutic biomarkers in tissue. Mogamulizumab is a defucosylated, humanized anti C-C chemokine receptor 4 (CCR4) monoclonal antibody that has been recently approved by the Food and Drug Administration (FDA) and the European Medicines Agency for the treatment of MF/ Sézary syndrome (SS). Mogamulizumab has been approved previously in Japan for relapsed or refractory CCR4-positive CTCL and peripheral T-cell lymphoma (PTCL) as well as for CCR4-positive adult T-cell leukaemia-lymphoma (ATLL). ${ }^{12}$ The FDA approval was based on the favorable results of the mogamulizumab versus vorinostat in previously treated CTCL (MAVORIC) trial. ${ }^{13}$ In MF/SS, which are characteristically CD4+ T-cell lymphomas, CCR4 is expressed on the dermal tumor cells and surrounding reactive T-cells, with its role in cell trafficking of malignant lymphocytes to the skin making it an attractive target for therapy. 14, 15 There is limited data on the expression of CCR4 in patients with CD8+ cutaneous lymphomas. In this study, we explored the expression of CCR4 within the spectrum of CD8+ CTCLs and LPDs and its potential as a treatment target in these rare diseases.

\section{Methods}

\section{Tissue samples}

The study was conducted with the approval of the institutional review board of Memorial Sloan Kettering Cancer Center. All included patients were evaluated and treated at our institution. Cases were identified from a pathology database search of our institutional tissue 
archive for CD8 predominant CTCLs and LPDs. Clinical charts and pathology reports and slides were reviewed in order to confirm diagnosis, as per the 2016 revision to the World Health Organization classification of lymphoid neoplasms. ${ }^{11}$

\section{Histopathology and immunohistochemistry (IHC)}

Hematoxylin and eosin-stained (H\&E) sections and archived available immunohistochemically stained sections were reviewed for expression of T-cell markers, including CD3, CD4, CD7, CD8, CD30, TCR $\beta$ and TCR 8 , and the presence of Epstein-Barr virus-encoded small RNA by in-situ hybridization. Further histologic pattern and immunophenotype was determined from review of pathology reports when slides were unavailable (Table II).

\section{IHC staining and interpretation of CCR4}

CCR4 IHC tissue staining was performed using a mouse anti-human CCR4 monoclonal antibody (clone L291H4; Biolegend \#359402) at $1.25 \mathrm{ug} / \mathrm{ml}$. Staining was performed on 4 $\mu \mathrm{m}$ formalin-fixed, paraffin-embedded tissue sections. Tissue sections were baked for one hour at $62^{\circ} \mathrm{C}$ and dewaxed on the Leica Bond. Antigen retrieval was performed in Leica ER2 solution for 30 minutes followed by 30 minutes of primary antibody incubation at room temperature. Antibody deposition was reported using DAB (Bond Polymer Refine Detection). CCR4 stained sections were reviewed by three of the coauthors. For each case, the percentage of the atypical lymphoid infiltrate positive for CCR 4 was evaluated by a reviewer who was blinded to the clinical diagnosis. CCR4 staining intensity was graded $1+$, $2+$ or $3+$. The size and location of CCR4-positive cells and staining pattern ((I) granular or diffuse and (II) cytoplasmic, perinuclear or membranous, were noted. Positive cases were subsequently stratified into two categories based on the percent of CCR4+ cells of the whole infiltrate using a natural cut point of 25\%: low expression if 0-25\% and high expression if $>25 \% .{ }^{12} \mathrm{H}$-score was calculated for each case by multiplying the percent of CCR4+ cells by the intensity grade.

\section{Results}

Forty-nine skin biopsies from 41 patients with CD8+ CTCL/LPDs were included (Table 1). Thirty-four cases (69\%) and 30 patients (73\%) showed any CCR4 expression. Seventeen cases (35\%) showed high levels of expression (>25\% of the infiltrate) as demonstrated in Fig 1. Clinical data and CCR4 IHC results are detailed in Table 2.

\section{CD8+ Mycosis Fungoides (MF).}

Of the 13 patients (14 cases) with CD8+ MF, upon presentation, two patients were staged with IA disease, nine with IB, one with IIA and one with IIB. CCR4 expression was seen in all MF cases. Eleven of 14 cases (79\%) showed high CCR4 expression. The two MF cases with the highest CCR4 expression (90\%) were patients with the most advanced clinical stages among the studied MF cases. In one patient with stage IB MF with large cell transformation, two lesions were evaluated 4.5 months apart: the first was a patch with $1 \%$ CCR4+ cells at 2+ intensity, and the later was an eroded plaque with 50\% CCR4+ at 3+ intensity. In all MF cases the CCR4 expressing cells were present in the dermis. In 9 cases 
CCR4 stained dermal cells only, while in two cases a few epidermotropic CCR4+ cells were seen; however, these were sparse compared to the overall epidermotropic CD8+ T-cell infiltrate. The CCR4 staining pattern was granular and cytoplasmic in most MF cases (11/13). One case appeared to have both cytoplasmic and membranous labeling and another case showed a cytoplasmic and perinuclear pattern. No association was seen between expression of CD30 and CCR4 expression in these cases.

\section{CD8+ CD30+ Lymphoproliferative disorders (LPD).}

Two of the 6 cases (33\%) of CD30+ LPDs showed high expression levels of CCR4 and one case (17\%) was completely negative. All CCR4+ cells in these cases were present in the dermis, except for one case in which CCR4+ cells were also sparsely present in the epidermis. The staining pattern was granular and cytoplasmic in all cases. In one case there was also perinuclear accentuation. No correlation was seen between CCR4 and CD30.

\section{Aggressive epidermotropic CD8+ cytotoxic T-cell lymphoma (AETCL).}

Eight cases from 4 patients were studied and 7/8 exhibited ulceration and other histologic evidence of cytotoxicity. Only one of 8 cases (12.5\%) showed high CCR4 expression (50\% of cells) and 2 cases (25\%) were completely negative. CCR4+ cells were localized to the dermis in all positive cases and were also present in the subcutis in two. CCR4+ cells were sparsely present in the epidermis in two cases. The staining pattern was diffuse and cytoplasmic in two cases and granular and cytoplasmic in four. Sequential biopsies were evaluated in three patients. In the first patient, two biopsies were performed within a week on different lesions showing 50\% CCR4+ cells at +3 intensity and $10 \%+1$. The second patient had two biopsies from the same ulcerating plaque 2.5 months apart: one showed $20 \%$ CCR 4 positivity at +2 intensity and $5 \%+1$ in the second. A third biopsy on a separate plaque showed no CCR4+ expression. Two biopsies in a third patient were performed within few days on different lesions showing $5 \%$ and no CCR4+ expression.

\section{Primary cutaneous $\gamma \delta$ T-cell lymphoma (GDTCL).}

Four of 6 biopsies in 5 patients with GDTCL were CCR4-negative and two (33\%) were CCR4-positive. One CCR4+ case showed localized CCR4 labeling comprising $60 \%$ of the whole infiltrate. In the second CCR4+ case, $5 \%$ of cells expressed CCR4. The staining pattern in both cases was diffuse and cytoplasmic. None of the GDTCL cases with epidermal or interface dermatitis showed any CCR4+ cells in these regions. Two separate biopsies were evaluated in one patient: one was a plaque showing 5\% CCR4 +1 , and another biopsy, performed 7 months later on an ulcerated plaque, showed no CCR4 staining.

\section{Subcutaneous panniculitis-like T-cell lymphoma (SPTCL).}

None of the 7 cases (6 patients) with SPTCL showed any CCR4 expression.

\section{Other subtypes and diagnostic conundrums.}

High CCR4 expression was seen in one case of PTCL, not otherwise specified (PTCL-NOS) with $30 \%$ positivity. A case of EBV+ CD8+ cutaneous T-cell lymphoma exhibited $40 \%$ CCR4+. All additional cases showed low CCR4 expression as detailed in Table 2, including 
another EBV-associated lymphoma, PTCL, NOS, CD8+ granulomatous CTCL and 2 patients with differential diagnoses of GDTCL vs MF and AETCL vs MF vs PTCL.

\section{Discussion}

CCR4 is a chemokine receptor preferentially expressed on T-helper type 2 (Th2) cells and certain regulatory $\mathrm{T}$ (Treg) cells which is involved in T-cell trafficking to the skin as well as in promoting cell growth and survival. ${ }^{16} \mathrm{CCR} 4$ has been reported to be expressed on a subset of memory CD4+ lymphocytes and only on a very small subset of CD8+ lymphocytes in the bloodstream. ${ }^{17} \mathrm{CCR} 4$ is expressed by neoplastic T-cells in several malignancies including ATLL, PTCL and CTCL. ${ }^{18}$ In CTCL, most lymphoma cells that are infiltrating the skin have been shown to be a subset of Th2-like memory cells expressing CLA, CD4, CD45RO and CCR $4 .{ }^{19}$ Interactions between CCR4 and its ligands have been suggested to play an important pathogenic role in $\mathrm{MF} / \mathrm{SS}^{14}$ and CCR4 expression has been reported to increase with advancing disease stage. ${ }^{20-22}$ Kallinich et al. identified an abundant expression of CCR4 on both tumor cells and reactive T-cells in MF lesions. They found CCR4 to be highly expressed on the malignant cells in patch/plaque and tumor stages of MF, while the fraction of CCR4+ cells in reactive components of cellular infiltrates was lower in more progressed stages. ${ }^{15}$ Therefore, CCR4 is considered to be an attractive therapeutic target with a direct effect on the neoplastic MF cells, as well as an influence on the tumor microenvironment. ${ }^{16}$

Little is known about CCR4 expression in CD8+ CTCL/LPDs. A CD8+ immunophenotype is seen in approximately $5 \%$ of MF cases. This immunophenotypic variant commonly manifests as early-stage disease, appearing most frequently in the pediatric population and in patients with darker skin as patches that are often hypopigmented. ${ }^{3}$ Compared to CD4+ disease, CD8+ MF has been shown to have a more indolent clinical course ${ }^{3,4}$ and therefore a conservative treatment approach using skin-directed therapies and observation has been recommended. ${ }^{3}$ On histopathology, CD8+ MF may appear similar to conventional CD4+ $\mathrm{MF}^{9}{ }^{9}$ but often without the classic Pautrier microabscesses ${ }^{3,4}$. Other histologic signs of a CD8+ variant of MF include vacuolar interface alteration with basal layer keratinocyte damage, concomitant, usually minor, karyorrhexis, and melanin incontinence. Predictably, some CD8+ MF as well as CD8+ CD30+ LPDs, specifically LyP type D, may display such a dramatic histologically cytotoxic phenotype that they are difficult to differentiate from AETCL or GDTCL. Clinically, AETCL presents as a diffuse eruption of ulcerated papules, plaques and tumors. ${ }^{23}$ GDTCL may present as an MF-like eruption, and may be CD8+. ${ }^{10,24}$ Unlike the first two, indolent diagnoses, the latter ones are aggressive diseases with very poor prognoses and their response to therapy is usually poor. ${ }^{1,5,}{ }^{8-10}$ In our study, IHC staining of CCR4 in paraffin-embedded skin tissue demonstrated high CCR4 expression in 11/14 (79\%) of CD8+ MF cases, 2/6 (33\%) of CD8+ CD30+ LPDs and only 1/8 (12.5\%), $1 / 6(17 \%)$ and $0 / 7$ (0\%) of AETCL, GDTCL and SPTCL cases, respectively. The mostly absent CCR4 expression of AETCL validates a prior study in which five AETCL cases were found to be CCR 4 negative, using a cutoff of $40 \%$ of stained cells for positivity. ${ }^{21}$ Furthermore, as previously reported, ${ }^{20-22}$ the cases from MF patients with more advanced disease had higher CCR4+ expression. These differences in IHC expression suggest that CCR4, although not specific, may have diagnostic utility in the differential diagnosis of 
CD8+ CTCL/LPDs, specifically in distinguishing advanced CD8+ MF from AETCL ${ }^{25}$ and GDTCL $^{26}$ as demonstrated in Fig 2.

SPTCL is a panniculitic T-cell lymphoma with a typical diffuse CD8+, $a \beta+$ immunophenotype. SPTCL often follows an indolent clinical course however it tends to show cytotoxic features that may be worrisome for an aggressive cutaneous lymphoma on histopathologic analysis. ${ }^{8}$ None of the seven cases with SPTCL that we studied showed any CCR4+ cells, suggesting that CCR4 doesn't play a role in SPTCL pathogenesis. A single SPTCL case has been previously reported with CCR4 and CCR5 positivity and it was suggested that CCR5 is related to the migration and proliferation of neoplastic cells into the subcutis instead of the epithelium. ${ }^{27}$

GDTCL is another CTCL subtype that presents with a panniculitic pattern in many cases. Although it is typically CD4-CD8-, some cases are CD8+. Our results showed negative CCR4 expression in most cases of CD8+ GDTCL (4/6, 67\%). High CCR4 expression was seen in a single case $(1 / 6,17 \%)$. Interestingly, no CCR4+ cells were seen in the epidermotropic or upper dermal infiltrates in the GDTCL cases with involvement of these compartments. A recent study of CCR4 expression in GDTCL reported positive expression in $1 / 10$ cases, and the positive case had a CD8+ phenotype and $20 \% \mathrm{CCR} 4+$ cells $^{28}$, similar to our case.

Due to the small number of cases with CD8+ granulomatous CTCL, EBV-associated lymphoma and PTCL-NOS that were included in our study we couldn't reach definitive conclusions regarding CCR4 in these disorders.

Regarding temporal heterogeneity of CCR4 expression, in seven patients, multiple biopsies were performed and most of them showed variability. In two cases (transformed MF and AETCL), the differences were marked, with low expression seen in the first biopsy and high expression (50\%) seen in the second. In other cases with inter-biopsy variability, the differences were less significant, and all cases were classified as having low expression. Previous studies have demonstrated inter and intra-lesional biomarker expression variability using IHC. ${ }^{29}$ Our paired varying cases, in the context of those studies, serve as a reminder that most IHC biomarkers should be used with a degree of caution. Results should be integrated with other histopathological and IHC data, and repeated biopsies from different sites and morphologies may be needed for treatment determination, particularly when therapeutic options are limited.

Overall our results regarding the CD8+ variant of MF are in line with and expand upon previous studies reporting that CCR4 IHC seems most useful in identifying this potential therapeutic biomarker in MF in general (most often CD4+ MF), in which CCR4 positivity correlates with advancing disease. ${ }^{20-22}$ Our data further provide a rationale for the use of anti-CCR4 therapies in CD8+ MF. The complete absence of CCR4 expression in SPTCL in our study suggests that this lymphoma subset may not be an ideal target for this therapy. The role of detection of CCR4 expression by IHC to support the therapeutic stratification of CD8+ CD30+ LPDs and other rare CD8+ CTCL subtypes is less clear 21,28 and should be further investigated. 
In conclusion, our study demonstrates that CCR4 is expressed differently within the spectrum of CD8+ CTCL/LPDs. The high CCR4 expression in CD8+ MF, mainly in advanced disease, may assist in differentiating it from other CD8+ CTCLs. While CCR4 may be an attractive therapeutic target in CD8+ MF, its potential in AETCL and GDTCL treatment is unclear.

\section{Acknowledgements}

Funding sources: This research was funded in part through the NIH/NCI Cancer Center Support Grant P30 CA008748. This research was supported by the Parker Institute for Cancer Immunotherapy at Memorial Sloan Kettering Cancer Center.

\section{References}

1. Wobser M, Reinartz T, Roth S, Goebeler M, Rosenwald A, Geissinger E. Cutaneous CD8+ Cytotoxic T-Cell Lymphoma Infiltrates: Clinicopathological Correlation and Outcome of 35 Cases. Oncol Ther 2016;4:199-210. [PubMed: 28261650]

2. Willemze R, Jaffe ES, Burg G et al. WHO-EORTC classification for cutaneous lymphomas. Blood 2005;105:3768-85. [PubMed: 15692063]

3. Martinez-Escala ME, Kantor RW, Cices A et al. CD8(+) mycosis fungoides: A low-grade lymphoproliferative disorder. J Am Acad Dermatol 2017;77:489-96. [PubMed: 28676328]

4. Nikolaou VA, Papadavid E, Katsambas A et al. Clinical characteristics and course of CD8+ cytotoxic variant of mycosis fungoides: a case series of seven patients. Br J Dermatol 2009;161:826-30. [PubMed: 19558552]

5. Saggini A, Gulia A, Argenyi Z et al. A variant of lymphomatoid papulosis simulating primary cutaneous aggressive epidermotropic CD8+ cytotoxic T-cell lymphoma. Description of 9 cases. Am J Surg Pathol 2010;34:1168-75. [PubMed: 20661014]

6. Kempf W, Kazakov DV, Scharer L et al. Angioinvasive lymphomatoid papulosis: a new variant simulating aggressive lymphomas. Am J Surg Pathol 2013;37:1-13. [PubMed: 23026936]

7. López-Lerma I, Peñate Y, Gallardo F et al. Subcutaneous panniculitis-like T-cell lymphoma: Clinical features, therapeutic approach, and outcome in a case series of 16 patients. J Am Acad Dermatol. 2018;79:892-898. [PubMed: 30126736]

8. Geller S, Myskowski PL, Pulitzer M, Horwitz SM, Moskowitz AJ. Cutaneous T-cell lymphoma (CTCL), rare subtypes: five case presentations and review of the literature. Chin Clin Oncol 2019;8:5. [PubMed: 30525759]

9. Robson A, Assaf C, Bagot M et al. Aggressive epidermotropic cutaneous CD8+ lymphoma: a cutaneous lymphoma with distinct clinical and pathological features. Report of an EORTC Cutaneous Lymphoma Task Force Workshop. Histopathology 2015;67:425-41. [PubMed: 24438036]

10. Geller S, Myskowski PL, Pulitzer M. NK/T-cell lymphoma, nasal type, gamma delta T-cell lymphoma, and CD8-positive epidermotropic T-cell lymphoma-clinical and histopathologic features, differential diagnosis, and treatment. Semin Cutan Med Surg 2018;37:30-8. [PubMed: 29719018]

11. Swerdlow SH, Campo E, Pileri SA et al. The 2016 revision of the World Health Organization classification of lymphoid neoplasms. 2016;127:2375-90.

12. Ogura M, Ishida T, Hatake K et al. Multicenter phase II study of mogamulizumab (KW-0761), a defucosylated anti-cc chemokine receptor 4 antibody, in patients with relapsed peripheral T-cell lymphoma and cutaneous T-cell lymphoma. J Clin Oncol 2014;32:1157-63. [PubMed: 24616310]

13. Kim YH, Bagot M, Pinter-Brown L et al. Mogamulizumab versus vorinostat in previously treated cutaneous T-cell lymphoma (MAVORIC): an international, open-label, randomised, controlled phase 3 trial. Lancet Oncol. 2018;19:1192-1204. [PubMed: 30100375] 
14. Kakinuma T, Sugaya M, Nakamura K et al. Thymus and activation-regulated chemokine (TARC/ CCL17) in mycosis fungoides: serum TARC levels reflect the disease activity of mycosis fungoides. J Am Acad Dermatol 2003;48:23-30. [PubMed: 12522366]

15. Kallinich T, Muche JM, Qin S, Sterry W, Audring H, Kroczek RA. Chemokine receptor expression on neoplastic and reactive $\mathrm{T}$ cells in the skin at different stages of mycosis fungoides. J Invest Dermatol 2003;121:1045-52. [PubMed: 14708605]

16. Wilcox RA. Mogamulizumab: 2 birds, 1 stone. Blood 2015;125:1847-8. [PubMed: 25792728]

17. Andrew DP, Ruffing N, Kim CH et al. C-C chemokine receptor 4 expression defines a major subset of circulating nonintestinal memory T cells of both Th1 and Th2 potential. J Immunol 2001;166:103-11. [PubMed: 11123282]

18. Ishida T, Inagaki H, Utsunomiya A et al. CXC chemokine receptor 3 and $\mathrm{CC}$ chemokine receptor 4 expression in T-cell and NK-cell lymphomas with special reference to clinicopathological significance for peripheral T-cell lymphoma, unspecified. Clin Cancer Res 2004;10:5494-500. [PubMed: 15328188]

19. Egawa G, Kabashima K. Skin as a peripheral lymphoid organ: revisiting the concept of skinassociated lymphoid tissues. J Invest Dermatol 2011;131:2178-85. [PubMed: 21734715]

20. Jones D, O'Hara C, Kraus MD, Perez-Atayde AR, Shahsafaei A, Wu L et al. Expression pattern of T-cell-associated chemokine receptors and their chemokines correlates with specific subtypes of Tcell non-Hodgkin lymphoma. Blood 2000;96:685-90. [PubMed: 10887135]

21. Yagi H, Seo N, Ohshima A et al. Chemokine receptor expression in cutaneous T cell and NK/T-cell lymphomas: immunohistochemical staining and in vitro chemotactic assay. Am J Surg Pathol 2006;30:1111-9. [PubMed: 16931956]

22. Sugaya M, Morimura S, Suga H et al. CCR4 is expressed on infiltrating cells in lesional skin of early mycosis fungoides and atopic dermatitis. J Dermatol 2015;42:613-5. [PubMed: 25809616]

23. Geller S, Pulitzer M, Myskowski PL. Diffuse eruptive ulcerated plaques. Int J Dermatol 2018;57:1055-7. [PubMed: 29693247]

24. Pulitzer M, Geller S, Kumar E et al. T-cell receptor-delta expression and gammadelta+ T-cell infiltrates in primary cutaneous gammadelta T-cell lymphoma and other cutaneous T-cell lymphoproliferative disorders. Histopathology 2018;73:653-62. [PubMed: 29893430]

25. Guitart J, Martinez-Escala ME, Subtil A et al. Primary cutaneous aggressive epidermotropic cytotoxic T-cell lymphomas: reappraisal of a provisional entity in the 2016 WHO classification of cutaneous lymphomas. Mod Pathol 2017;30:761-72. [PubMed: 28128277]

26. Guitart J, Weisenburger DD, Subtil A et al. Cutaneous gammadelta T-cell lymphomas: a spectrum of presentations with overlap with other cytotoxic lymphomas. Am J Surg Pathol 2012;36:165665. [PubMed: 23073324]

27. Kitayama N, Otsuka A, Honda Y, Matsumura Y, Honda T, Kabashima K. CCR4 and CCR5 expression in a case of subcutaneous panniculitis-like T-cell lymphoma. Eur J Dermatol 2017;27:414-5. [PubMed: 28721932]

28. Jour G, Aung PP, Merrill ED et al. Differential expression of CCR4 in primary cutaneous gamma/ delta (gammadelta) T cell lymphomas and mycosis fungoides: Significance for diagnosis and therapy. J Dermatol Sci 2018;89:88-91. [PubMed: 29030090]

29. Rahbar Z, Li S, Tavallaee M, Novoa RA, Kim J, Kim YH. Variability in the Expression of Immunohistochemical Markers: Implications for Biomarker Interpretation in Cutaneous T-Cell Lymphoma. J Invest Dermatol 2018;138:1204-6. [PubMed: 29247659] 


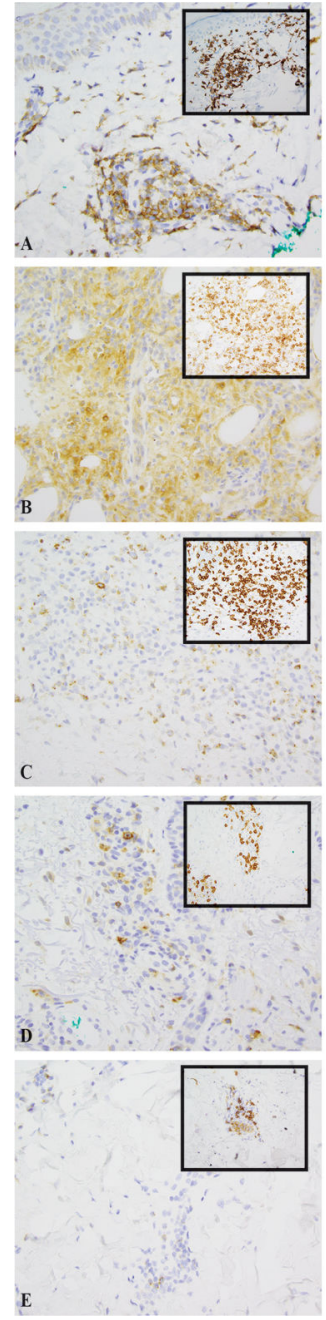

Figure 1.

C-C chemokine receptor 4 (CCR4) immunohistochemical staining in CD8+ cutaneous T-cell lymphomas and lymphoproliferative disorders. The corresponding CD8 stain is shown in the insert on the upper right corner of each case. A, High level of CCR4 expression (90\%) at 3+ intensity showing a granular cytoplasmic pattern (patient 1). B, High level of CCR4 expression (60\%) at $2+$ to $3+$ intensity and diffuse cytoplasmic pattern (patient 30). C, High level of CCR4 expression $(30 \%)$ at 2+ intensity with granular cytoplasmic pattern (patient 11). D, Low level of CCR4 expression (20\%) at 2+ intensity and granular cytoplasmic and perinuclear patterns (patient 18). E, Low level of CCR4 expression (10\%) at 1+ intensity and granular cytoplasmic staining pattern (patient 20). 

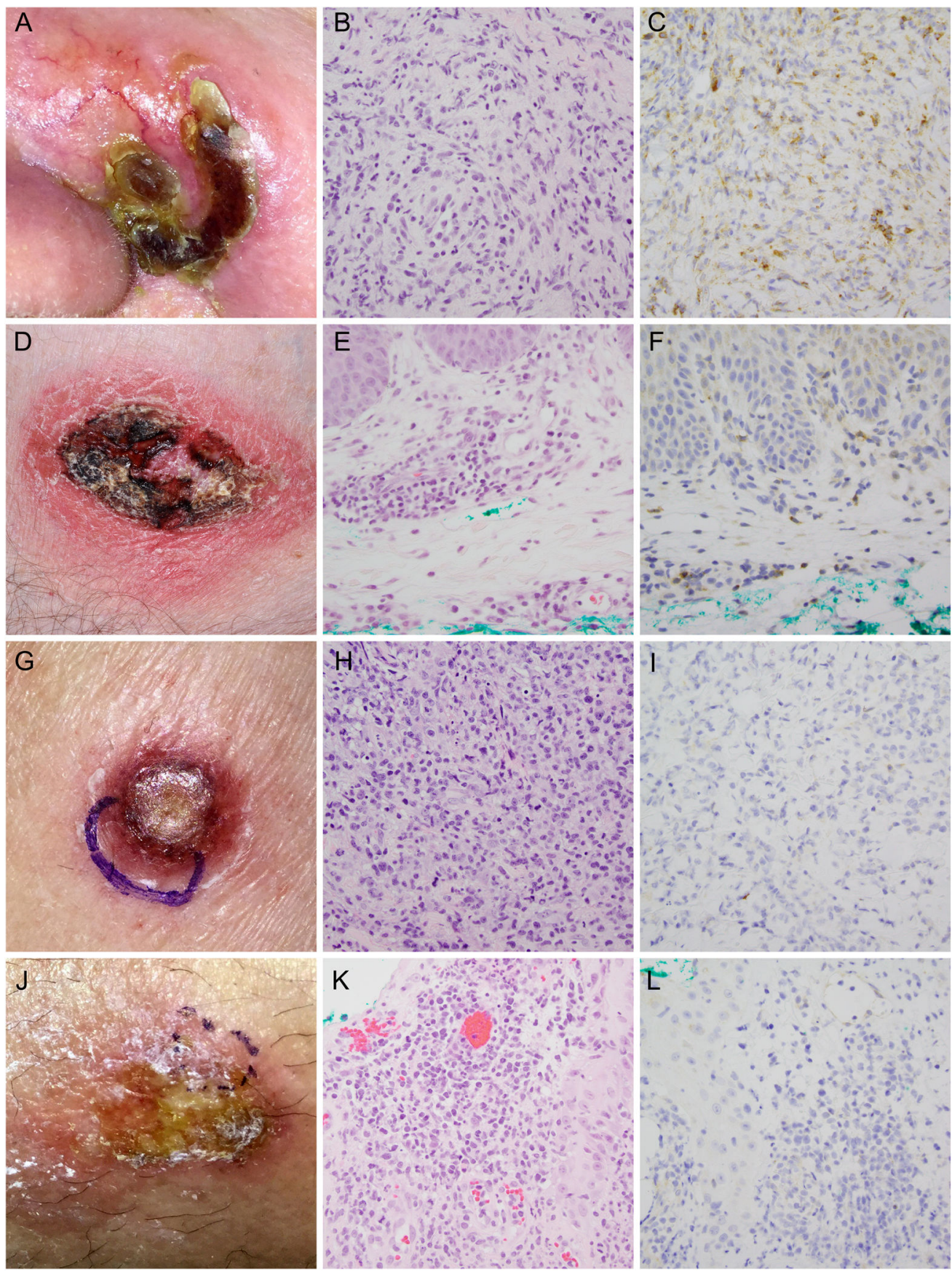

Figure 2.

C-C chemokine receptor 4 (CCR4) is expressed differently in CD8+ cutaneous T-cell lymphomas and lymphoproliferative disorders presenting as ulcerated papules/ plaques.

A-C, Tumor stage CD8+ mycosis fungoides (patient 2). A, Ulcerated tumor. B, Skin biopsy showing a pan-dermal atypical lymphocytic infiltrate on haematoxylin and eosin (H\&E). C, CCR4 stains $\sim 90 \%$ of the infiltrate. 
D-F, Aggressive epidermotropic T-cell lymphoma (patient 21). D, Ulcerated plaque. E, Superficial dermal and epidermotropic atypical lymphocytic infiltrate on H\&E. F, CCR4 expression seen in $20 \%$ of the dermal infiltrate.

G-I, CD30+ lymphoproliferative disorder (patient 19). G, Ulcerated papule. H, H\&E showing atypical lymphocytic infiltrate involving the dermis and subcutis. I, No CCR4 expression is seen $(0 \%)$.

J-L, Gamma delta T-cell lymphoma (patient 33). J, Ulcerated plaque. K, Dermal infiltrate of atypical lymphocytes. $\mathbf{L}, \mathrm{CCR} 4$ expression is $0 \%$. 
Table 1.

Percent of labeling of CD8+ cutaneous T-cell lymphoma and lymphoproliferative disorder type by CCR4 immunohistochemistry

\begin{tabular}{lccc}
\hline CD8+ CTCL/LPD Diagnosis & Number of cases (patients) & $\begin{array}{c}\text { Cases with None to Low CCR4 } \\
\text { expression (0-25\% cells) }\end{array}$ & $\begin{array}{c}\text { Cases with High CCR4 } \\
\text { expression (>25\% cells) }\end{array}$ \\
\hline CD8+ MF & $14(13)$ & 3 & 11 \\
CD8+ CD30+ LPD & $6(6)$ & 4 & 2 \\
AETCL & $8(4)$ & 7 & 1 \\
SPTCL & $7(6)$ & 7 & 0 \\
GDTCL & $6(5)$ & 5 & 1 \\
CD8+ granulomatous CTCL & $2(1)$ & 2 & 0 \\
EBV-associated lymphoma & $2(2)$ & 1 & 1 \\
PTCL, nos & $2(2)$ & 1 & 1 \\
Diagnostic conundrums & $1(1)$ & 1 & 0 \\
AETCL vS MF vS PTCL & $1(1)$ & 1 & 0 \\
GDTCL vS MF & $\mathbf{4 9}(\mathbf{4 1}$ & $\mathbf{3 2}$ & $\mathbf{1 7}$ \\
TOTAL & & & 1 \\
\hline
\end{tabular}

MF, mycosis fungoides; LPD, lymphoproliferative disorder; AETCL, aggressive epidermotropic T-cell lymphoma; CTCL, cutaneous T-cell lymphoma; SPTCL, subcutaneous panniculitis-like T-cell lymphoma; GDTCL, gamma delta T-cell lymphoma; PTCL, nos, peripheral T-cell lymphoma, not otherwise specified; TMF, transformed MF; EBV - Epstein-Barr virus. 
Table 2.

CD8+ cutaneous T-cell lymphoma and lymphoproliferative disorder cases with CCR4 expression and characteristics of CCR4 immunohistochemistry

\begin{tabular}{|c|c|c|c|c|c|c|c|c|}
\hline \multirow[b]{2}{*}{$\begin{array}{l}\text { Pt. } \\
\text { no. }\end{array}$} & \multirow[b]{2}{*}{$\begin{array}{l}\text { Age, } \\
\text { Sex }\end{array}$} & \multirow[b]{2}{*}{$\begin{array}{l}\text { Cutaneous T-cell } \\
\text { lymphoma } \\
\text { diagnosis }\end{array}$} & \multirow[b]{2}{*}{$\begin{array}{c}\text { Lesion } \\
\text { (morphology, } \\
\text { anatomic site) }\end{array}$} & \multirow[b]{2}{*}{$\begin{array}{c}\text { Histologic } \\
\text { pattern }\end{array}$} & \multirow[b]{2}{*}{$\begin{array}{l}\text { Percent of } \\
\text { infiltrate }\end{array}$} & \multicolumn{3}{|c|}{ CCR4 expression } \\
\hline & & & & & & $\begin{array}{l}\text { Intensity } \\
(1+\text { to } 3+)\end{array}$ & $\begin{array}{l}\text { H-score } \\
(\% \text { of } \\
\text { infiltrate } \\
\times \\
\text { intensity })\end{array}$ & localization \\
\hline 1 & $\mathrm{~F} / 64$ & $\begin{array}{l}\text { CD8+ MF, stage } \\
\text { IIA }\end{array}$ & Patch, thigh & $\begin{array}{l}\text { Epidermotropic, } \\
\text { dermal }\end{array}$ & $90 \%$ & $3+$ & 270 & $\begin{array}{l}\text { Dermal, } \\
\text { perivascular }\end{array}$ \\
\hline 2 & $\mathrm{M} / 71$ & $\begin{array}{l}\text { CD8+ MF, stage } \\
\text { IIB }\end{array}$ & $\begin{array}{l}\text { Ulcerated tumor, } \\
\text { cheek }\end{array}$ & Dermal & $90 \%$ & $2+$ & 180 & Dermal \\
\hline 3 & $\mathrm{~F} / 81$ & $\begin{array}{l}\text { CD8+ MF, stage } \\
\text { IB }\end{array}$ & Patch, axilla & $\begin{array}{l}\text { Epidermotropic, } \\
\text { dermal }\end{array}$ & $80 \%$ & $2+$ & 160 & $\begin{array}{l}\text { Dermal, } \\
\text { epidermotropic } \\
\text { (sparse) }\end{array}$ \\
\hline 4 & $\mathrm{M} / 56$ & $\begin{array}{l}\text { CD8+ MF, stage } \\
\text { IB }\end{array}$ & $\begin{array}{l}\text { Patch/Plaque, } \\
\text { buttock }\end{array}$ & $\begin{array}{l}\text { Epidermotropic, } \\
\text { dermal }\end{array}$ & $70 \%$ & $3+$ & 210 & Dermal \\
\hline 5 & $\mathrm{M} / 88$ & $\begin{array}{l}\text { CD8+ TMF, stage } \\
\text { IB }\end{array}$ & $\begin{array}{l}\text { Eroded plaque, } \\
\text { back }\end{array}$ & Dermal & $50 \%$ & $3+$ & 150 & Dermal \\
\hline 6 & $\mathrm{M} / 53$ & $\begin{array}{l}\text { CD8+ MF, stage } \\
\text { IA }\end{array}$ & Plaque, buttock & $\begin{array}{l}\text { Epidermotropic, } \\
\text { dermal }\end{array}$ & $40 \%$ & $3+$ & 120 & $\begin{array}{l}\text { Dermal, } \\
\text { perivascular, } \\
\text { epidermotropic } \\
\text { (sparse) }\end{array}$ \\
\hline 7 & $\mathrm{~F} / 57$ & $\begin{array}{l}\text { CD8+ MF, stage } \\
\text { IB }\end{array}$ & Plaque, chest & $\begin{array}{l}\text { Epidermotropic, } \\
\text { dermal, } \\
\text { perivascular }\end{array}$ & $40 \%$ & $3+$ & 120 & $\begin{array}{l}\text { Dermal, } \\
\text { perivascular }\end{array}$ \\
\hline 8 & $\mathrm{M} / 61$ & $\begin{array}{l}\text { CD8+ MF, stage } \\
\text { IB }\end{array}$ & Plaque, foot & Dermal & $40 \%$ & $2+$ & 80 & Dermal \\
\hline 9 & $\mathrm{~F} / 42$ & $\begin{array}{l}\text { CD8+ MF, stage } \\
\text { IB }\end{array}$ & Patch, thigh & $\begin{array}{l}\text { Epidermotropic, } \\
\text { dermal }\end{array}$ & $40 \%$ & $2+$ & 80 & Dermal \\
\hline 10 & $\mathrm{M} / 59$ & $\begin{array}{l}\text { CD8+ MF, stage } \\
\text { IA }\end{array}$ & Patch, buttock & Epidermotropic & $30 \%$ & $3+$ & 90 & Dermal \\
\hline 11 & $\mathrm{~F} / 49$ & $\begin{array}{l}\text { CD8+ MF, stage } \\
\text { IB }\end{array}$ & Plaque, thigh & $\begin{array}{l}\text { Epidermotropic, } \\
\text { dermal }\end{array}$ & $30 \%$ & $2+$ & 60 & Dermal \\
\hline 12 & $\mathrm{M} / 54$ & $\begin{array}{l}\text { CD8+ MF, stage } \\
\text { IB }\end{array}$ & Plaque, thigh & $\begin{array}{l}\text { Epidermotropic, } \\
\text { dermal }\end{array}$ & $20 \%$ & $2+$ & 40 & Dermal \\
\hline 5 & $\mathrm{M} / 88$ & $\begin{array}{l}\text { CD8+ TMF, stage } \\
\text { IB }\end{array}$ & Patch, abdomen & $\begin{array}{l}\text { Epidermotropic, } \\
\text { dermal }\end{array}$ & $1 \%$ & $2+$ & 2 & Dermal \\
\hline 13 & $\mathrm{M} / 35$ & $\begin{array}{l}\text { CD8+ MF, stage } \\
\text { IB }\end{array}$ & Patch, buttock & Epidermal & Positive * & $\mathrm{n} / \mathrm{a}$ & $\mathrm{n} / \mathrm{a}$ & $\mathrm{n} / \mathrm{a}$ \\
\hline 14 & $\mathrm{M} / 58$ & CD30+ LPD & Nodule, breast & Dermal & $90 \%$ & $3+$ & 270 & Dermal \\
\hline 15 & $\mathrm{~F} / 88$ & CD30+ LPD & Nodule, leg & $\begin{array}{l}\text { Epidermotropic, } \\
\text { dermal, } \\
\text { subcutaneous }\end{array}$ & $90 \%$ & $2+$ & 180 & Dermal \\
\hline 16 & $F / 39$ & CD30+ LPD & Papule, arm & $\begin{array}{l}\text { Dermal, } \\
\text { perivascular }\end{array}$ & $25 \%$ & $3+$ & 75 & $\begin{array}{l}\text { Dermal, } \\
\text { perivascular, } \\
\text { epidermotropic } \\
\text { (sparse) }\end{array}$ \\
\hline 17 & $\mathrm{~F} / 45$ & CD30+ LPD & Papule, arm & $\begin{array}{l}\text { Epidermotropic, } \\
\text { dermal, } \\
\text { perivascular, } \\
\text { periadnexal }\end{array}$ & $20 \%$ & $2+$ & 40 & Dermal \\
\hline 18 & $\mathrm{M} / 72$ & CD30+ LPD & Papule, arm & Dermal. follicular & $20 \%$ & $2+$ & 40 & Dermal \\
\hline
\end{tabular}

Histopathology. Author manuscript; available in PMC 2021 January 01. 


\begin{tabular}{|c|c|c|c|c|c|c|c|c|}
\hline \multirow[b]{2}{*}{$\begin{array}{l}\text { Pt. } \\
\text { no. }\end{array}$} & \multirow[b]{2}{*}{$\begin{array}{l}\text { Age, } \\
\text { Sex }\end{array}$} & \multirow[b]{2}{*}{$\begin{array}{l}\text { Cutaneous T-cell } \\
\text { lymphoma } \\
\text { diagnosis }\end{array}$} & \multirow[b]{2}{*}{$\begin{array}{c}\text { Lesion } \\
\text { (morphology, } \\
\text { anatomic site) }\end{array}$} & \multirow[b]{2}{*}{$\begin{array}{c}\text { Histologic } \\
\text { pattern }\end{array}$} & \multicolumn{3}{|c|}{ CCR4 expression } & \multirow[b]{2}{*}{ localization } \\
\hline & & & & & $\begin{array}{l}\text { Percent of } \\
\text { infiltrate }\end{array}$ & $\begin{array}{l}\text { Intensity } \\
(1+\text { to } 3+)\end{array}$ & $\begin{array}{l}\text { H-score } \\
(\% \text { of } \\
\text { infiltrate } \\
\times \\
\text { intensity })\end{array}$ & \\
\hline 19 & $\mathrm{~F} / 36$ & CD30+ LPD & Papule, forearm & $\begin{array}{l}\text { Dermal. } \\
\text { subcutaneous }\end{array}$ & $0 \%$ & & & \\
\hline 20 & $\mathrm{M} / 44$ & AETCL & $\begin{array}{l}\text { Ulcerated } \\
\text { plaque, chest }\end{array}$ & $\begin{array}{l}\text { Epidermotropic } \\
\text { folliculotropic, } \\
\text { syrngiotropic }\end{array}$ & $50 \%$ & $3+$ & 150 & $\begin{array}{l}\text { Dermal, } \\
\text { folliculotropic, } \\
\text { epidermotropic } \\
\text { (sparse) }\end{array}$ \\
\hline 21 & $\mathrm{M} / 86$ & AETCL & $\begin{array}{l}\text { Ulcerated } \\
\text { plaque, abdomen }\end{array}$ & Epidermotropic & $20 \%$ & $2+$ & 40 & $\begin{array}{l}\text { Dermal, } \\
\text { epidermotropic } \\
\text { (sparse) }\end{array}$ \\
\hline 22 & $\mathrm{~F} / 86$ & AETCL & Ulcer, leg & $\begin{array}{l}\text { dermal and } \\
\text { subcutaneous }\end{array}$ & $10 \%$ & $2+$ & 20 & $\begin{array}{l}\text { dermal and } \\
\text { subcutaneous }\end{array}$ \\
\hline 20 & $\mathrm{M} / 44$ & AETCL & $\mathrm{n} / \mathrm{a}$ & $\begin{array}{l}\text { Epidermotropic, } \\
\text { dermal and } \\
\text { folliculotropic }\end{array}$ & $10 \%$ & $1+$ & 10 & $\begin{array}{l}\text { Dermal, } \\
\text { perivascular }\end{array}$ \\
\hline 23 & $\mathrm{~F} / 92$ & AETCL & $\begin{array}{l}\text { Necrotic papule, } \\
\text { back }\end{array}$ & $\begin{array}{l}\text { Epidermotropic, } \\
\text { dermal }\end{array}$ & $5 \%$ & $2+$ & 10 & Dermal \\
\hline 21 & $\mathrm{M} / 86$ & AETCL & $\begin{array}{l}\text { Ulcerated } \\
\text { plaque, abdomen }\end{array}$ & $\begin{array}{l}\text { dermal, } \\
\text { subcutaneous }\end{array}$ & $5 \%$ & $1+$ & 5 & $\begin{array}{l}\text { dermal and } \\
\text { subcutaneous }\end{array}$ \\
\hline 21 & $\mathrm{M} / 86$ & AETCL & Plaque, eyelid & $\begin{array}{l}\text { Dermal, } \\
\text { subcutaneous }\end{array}$ & $0 \%$ & & & \\
\hline 23 & $\mathrm{~F} / 92$ & AETCL & Papule, arm & dermal & $0 \%$ & & & \\
\hline 24 & $\mathrm{M} / 43$ & SPTCL & Nodule, chest & subcutaneous & $0 \%$ & & & \\
\hline 25 & $\mathrm{~F} / 30$ & SPTCL & $\mathrm{n} / \mathrm{a}$ & Subcutaneous & $0 \%$ & & & \\
\hline 26 & $\mathrm{M} / 81$ & SPTCL & Nodule, arm & $\begin{array}{l}\text { Subcutaneous, } \\
\text { dermal }\end{array}$ & $0 \%$ & & & \\
\hline 27 & $\mathrm{~F} / 2$ & SPTCL & Nodule, axilla & Subcutaneous & $0 \%$ & & & \\
\hline 28 & $\mathrm{M} / 31$ & SPTCL & Nodule, back & Subcutaneous & $0 \%$ & & & \\
\hline 29 & $\mathrm{M} / 15$ & SPTCL & Mass, face & Subcutaneous & $0 \%$ & & & \\
\hline 29 & $\mathrm{M} / 15$ & SPTCL & Mass, face & Subcutaneous & $0 \%$ & & & \\
\hline 30 & $\mathrm{M} / 45$ & GDTCL & Nodule, leg & Subcutaneous & $60 \%$ & $3+$ & 180 & $\begin{array}{l}\text { Subcutaneous } \\
\text { (focal) }\end{array}$ \\
\hline 31 & $\mathrm{M} / 40$ & GDTCL & Plaque, thigh & $\begin{array}{l}\text { Subcutaneous, } \\
\text { periadnexal }\end{array}$ & $5 \%$ & $1+$ & 5 & $\begin{array}{l}\text { Subcutaneous } \\
\text { and periadnexal }\end{array}$ \\
\hline 31 & $\mathrm{M} / 41$ & GDTCL & $\begin{array}{l}\text { Ulcerated } \\
\text { plaque, leg }\end{array}$ & $\begin{array}{l}\text { Subcutaneous, } \\
\text { dermal }\end{array}$ & $0 \%$ & & & \\
\hline 32 & $\mathrm{M} / 57$ & GDTCL & Tumor, neck & $\begin{array}{l}\text { Subcutaneous, } \\
\text { dermal, } \\
\text { epidermotropic, } \\
\text { folliculotropic }\end{array}$ & $0 \%$ & & & \\
\hline 33 & $\mathrm{M} / 79$ & GDTCL & $\begin{array}{l}\text { Ulcerated } \\
\text { plaque, leg }\end{array}$ & Dermal & $0 \%$ & & & \\
\hline 34 & $\mathrm{M} / 62$ & GDTCL & Nodule, forearm & $\begin{array}{l}\text { Subcutaneous, } \\
\text { dermal }\end{array}$ & $0 \%$ & & & \\
\hline 35 & $\mathrm{M} / 76$ & $\begin{array}{l}\text { CD8+ } \\
\text { granulomatous } \\
\text { CTCL }\end{array}$ & Plaque, abdomen & $\begin{array}{l}\text { Epidermotropic, } \\
\text { dermal, } \\
\text { subcutaneous }\end{array}$ & $25 \%$ & $3+$ & 75 & $\begin{array}{l}\text { Dermal, } \\
\text { perivascular, } \\
\text { Subcutaneous }\end{array}$ \\
\hline 35 & $\mathrm{M} / 76$ & $\begin{array}{l}\text { CD8+ } \\
\text { granulomatous } \\
\text { CTCL }\end{array}$ & Plaque, forearm & $\begin{array}{l}\text { Epidermotropic, } \\
\text { dermal }\end{array}$ & $10 \%$ & $2+$ & 20 & $\begin{array}{l}\text { Epidermotropic, } \\
\text { dermal }\end{array}$ \\
\hline
\end{tabular}

Histopathology. Author manuscript; available in PMC 2021 January 01. 


\begin{tabular}{|c|c|c|c|c|c|c|c|c|}
\hline \multirow[b]{2}{*}{$\begin{array}{l}\text { Pt. } \\
\text { no. }\end{array}$} & \multirow[b]{2}{*}{$\begin{array}{l}\text { Age, } \\
\text { Sex }\end{array}$} & \multirow[b]{2}{*}{$\begin{array}{l}\text { Cutaneous T-cell } \\
\text { lymphoma } \\
\text { diagnosis }\end{array}$} & \multirow[b]{2}{*}{$\begin{array}{c}\text { Lesion } \\
\text { (morphology, } \\
\text { anatomic site) }\end{array}$} & \multirow[b]{2}{*}{$\begin{array}{c}\text { Histologic } \\
\text { pattern }\end{array}$} & \multicolumn{3}{|c|}{ CCR4 expression } & \multirow[b]{2}{*}{ localization } \\
\hline & & & & & $\begin{array}{l}\text { Percent of } \\
\text { infiltrate }\end{array}$ & $\begin{array}{l}\text { Intensity } \\
(1+\text { to } 3+)\end{array}$ & $\begin{array}{l}\text { H-score } \\
(\% \text { of } \\
\text { infiltrate } \\
\times \\
\text { intensity })\end{array}$ & \\
\hline 36 & $\mathrm{M} / 56$ & $\begin{array}{l}\text { EBV-associated } \\
\text { lymphoma }\end{array}$ & Nodule, arm & Dermal & $40 \%$ & $1+$ & 40 & Dermal \\
\hline 37 & $\mathrm{~F} / 55$ & $\begin{array}{l}\text { EBV-associated } \\
\text { lymphoma }\end{array}$ & Patch, abdomen & $\begin{array}{l}\text { Dermal, } \\
\text { perivascular }\end{array}$ & $2 \%$ & $2+$ & 4 & Dermal \\
\hline 38 & $\mathrm{~F} / 49$ & PTCL, NOS & $\begin{array}{l}\text { Ulcerated } \\
\text { plaque, lip }\end{array}$ & $\begin{array}{l}\text { Epidermotropic, } \\
\text { dermal }\end{array}$ & $30 \%$ & $3+$ & 90 & Dermal \\
\hline 39 & $\mathrm{~F} / 76$ & PTCL, NOS & Tumor, chest & Dermal & $1 \%$ & $2+$ & 2 & Dermal \\
\hline 40 & $\mathrm{M} / 14$ & GDTCL vs MF & Papule, thigh & $\begin{array}{l}\text { Epidermotropic, } \\
\text { dermal }\end{array}$ & $2 \%$ & $2+$ & 4 & Dermal \\
\hline 41 & $F / 67$ & $\begin{array}{l}\text { AETCL vs } M F \text { vs } \\
\text { PTCL }\end{array}$ & $\begin{array}{l}\text { Ulcerated tumor, } \\
\text { breast }\end{array}$ & $\begin{array}{l}\text { Epidermotropic } \\
\text { (focal), dermal }\end{array}$ & $0 \%$ & & & \\
\hline
\end{tabular}

Sample was difficult to evaluate due to technical issues but was ultimately determined to show low CCR4 expression (1-10\%).

CCR4, C-C chemokine receptor 4; MF, mycosis fungoides; LPD, lymphoproliferative disorder; AETCL, aggressive epidermotropic T-cell lymphoma; CTCL, cutaneous T-cell lymphoma; SPTCL, subcutaneous panniculitis-like T-cell lymphoma; GDTCL, gamma delta T-cell lymphoma; PTCL, NOS, peripheral T-cell lymphoma, not otherwise specified; TMF, transformed MF; EBV - Epstein-Barr virus. 